\title{
МІЛІТАРНЕ ПРОТИСТОЯННЯ У ЛИСТОПАДОВОМУ ПОВСТАННІ 1830-1831 рр. НА ПРАВОБЕРЕЖНІЙ УКРАЇНІ
}

Стаття присвячена аналізу збройного антагонізму частин російської імператорської армії 3 загонами польських повстанців упродовж подій Листопадового повстання 1830-1831 pp. у Правобережній Україні. Розглянуто і висвітлено мотиваційні чинники протиборчих сторін, співвідношення сил, їх розташування, збройні зіткнення та маневри, тактичні успіхи і прорахунки. Об'єктом дослідження стала територія регіону, яка розглядається як театр воєнних дій відповідно до існуючого на той час адміністративнотериторіального поділу.

Ключові слова: Правобережна Україна, російське військо, польські повстанці, бойові дії, дислокація, ворожнеча.

Постановка проблеми та ї̈ актуальність. Унаслідок трьох поділів Речі Посполитої (1772, 1793, 1795 рр.) колись потужна країна припинила своє існування як суб'єкт європейської політики. Однак попри численні протиріччя у польському суспільстві, породжені кризою державницького устрою, поляки не бажали змиритися із втратою незалежності й усіляко підтримували ідею іiі відродження шляхом збройної боротьби. 3 імперією Романових вона розпочалася майже одразу ж після анексії: наприкінці XVIII ст. 3 повстання під проводом Т. Костюшка у 1794 р.; далі - активна участь у наполеонівському поході на Росію, а на початку $1830-$ х років XIX ст. вибухнуло потужне повстання, головною метою якого стало прагнення відродження Польщі через звільнення від російського імперського ярма. Відомо, що масштабний виступ охопив землі Польського Королівства, майже всю територію Білорусі, частину Литви та Правобережну Україну, яка входила до складу Російської імперії.

Скрипник Анатолій Юрійович - доктор історичних наук, доцент, завідувач кафедри інформаційної діяльності, документознавства i фундаментальних дисциплін Подільського спеціального навчально-реабілітаційного соціально-економічного коледжу, м. Кам'янець-Подільський.

(C) Скрипник А.Ю., 2018 
Мета $i$ завдання дослідження. Протягом чотирьох місяців 1831 р. на реренах Правобережної України тривала заповзята та драматична боротьба, що охопила майже всі етнічні й соціальні групи у кожному з регіонів (Київщина, Поділля, Волинь). Крім політичного шляху, направленого на відродження суверенітету, основним видом спротиву став саме збройний. Відповідно, російське самодержавство робило ставку на суто силовий, радикальний варіант вирішення проблеми. Як наслідок, з одного боку фігурують польські військові формування (зокрема, корпус генерала Ю. Дверницького та повстанські загони шляхти), 3 іншого - регулярні частини російської імператорської армії, іррегулярні козацькі полки з Лівобережної України та допоміжні підрозділи корпусу Внутрішньої сторожі (губернські батальйони та повітові роти). Саме дослідження польсько-російського військового протистояння стало головним завданням цієї публікації й присвячене суто мілітарній проблематиці.

Аналіз попередніх досліджень $і$ публікацій. Студіювання подій польського патріотичного листопадового повстання 1830-1831 pр. створило потужну історіографію. Наукові розвідки, що тривають більше ніж сто п'ятдесят років, дали можливість детально й поетапно відтворити усі стадії та потуги поляків, направлені на відновлення незалежності через збройну боротьбу проти російського царату. Природно, що чимала частка досліджень належить польським історикам: у XIX ст. - це Й. Лелевель та Ф. Вротновський [4; 7]; у другій половині XX ст. - Е. Козловський, А. Голінський, М. Мохнацький, В. Заєвський, С. Києневич, А. Загорський, Т. Гасовський, Н. Каспарек, М. Тромбський $[1 ; 2$; $3 ; 5 ; 6]$. Відзначаючи масове духовне піднесення, героїзм повстанців, їхню самопожертву, учені головною причиною поразки вважають саме військовий фактор. Попри усі позитивні чинники патріотизму було важко змагатися 3 більшими за кількістю та краще озброєними російськими регулярними полками.

Разом 3 тим ця історична тема перебуває у фокусі дослідження й українських фахівців, які активно здійснюють пошуки нових документальних свідчень і вивчають архівні документи. Розуміючи глобальне значення проблеми, яка через свою майже двохсотрічну давність не втратила актуальності й у другому десятиріччі XXI ст., науковці I. Ярмошик, I. Кривошея, 
I. Романюк $[46 ; 19 ; 28]$ намагаються об’єктивно висвітлювати ті далекі події через відтворення реального стану соціальних взаємовідносин у регіоні.

Виклад основного матеріалу. Насамперед, на нашу думку, варто окремо зупинитися на мотиваційних рушіях поляків i росіян, що відігравали далеко не останню роль у прагненнях обох сторін до досягнення намічених цілей i, врешті-решт, до остаточної перемоги. У першій половині XIX ст. російська армія була ефективним і зручним інструментом насильства в руках самодержавства. Для російського солдата 3 перших років анексії Правобережної України поляк став безперечно підкореним, але заклятим ворогом, і ставлення до нього було відповідним. Посилення ненависті росіян до поляків походило 3 найвищих кабінетів. Катерина II у грудні 1792 р. писала послу в Речі Посполитій Я. Сіверсу: „Ми переконані щодо непостійності й легковажності цього народу, про доведену його злобу та ненависть до всього нашого [...] ми в ньому ніколи не будемо мати спокійного i безпечного сусіда, якщо не зробимо їх безсилими і немічними" [14, с. 71]. Такі настрої цілеспрямовано вкорінювалися в тодішньому російському суспільстві. В армуйському середовищі їх спочатку підхопили генерали та офіцери, а потім вони поширилися серед рядових солдатів [15, с. 61]. Наприклад, ось характеристика, змішана 3 ненавистю: „Коли поляк щасливий, то він гордий, пихатий та неприступний, а коли нещастя - то тихий, підлий та улесливий. Ні багатство, ні високий чин, ні стрічки на плечах, ні зірки на грудях не можуть замінити запаморочення та порожне серце" [27, л. 11-12]. 3 початком повстання російське суспільство надало моральну індульгенцію солдатам на насилля через поширення відомостей про „нелюдяні звірства повстанців на чолі 3 католицькими священиками", які ніхто не перевіряв, але яким усі вірили [45, c. 92]. Простий російський люд також був переконаний у зрадництві, невдячності, зарозумілості та легковажності поляків. Казали: „Поляків коли б'ють, то за те, що поляк бунтує [...] він 3 давніх часів каламутить Російську землю, за те й б'ють” [9, с. 332].

Відповіддю поляків стало зростання пасивного спротиву, яке вилилося у майже відкриту демонстрацію своєї ненависті до окупантів, як-то носіння каблучок-талісманів з написом: „Dopoki 
swiat stoi swiatem, polak ruskomu nie bedzie bratem [20, c. 136; 138], чи більш лаконічними „Niech żyje Polska!”, а також зберігання і розповсюджування поміщиками творів А. Міцкевича, виконання у костелах патріотичних пісень і гімнів. В. Шульгін писав: „Тільки-но дитина починала усвідомлювати себе, як іï одразу ж лякали москалем, потім вчили виколювати очі на портретах росіян. Разом з тим, враховуючи їх вік, розвивали думки і мрії про воскресіння багатостраждальної мучениці-відчизни” [32, с. 259].

Таким чином, на той час підрозділи російської армії у Правобережній Україні та Царстві Польському відчували себе ніби на окупованій ворожій території, де, як і на Кавказі, постійно потрібно було бути готовими до раптових нападів чи бунтів. Безперечно, це накладало певний відбиток на сам факт перебування збройних сил імперії в цьому регіоні, особливо перші два десятиріччя XIX ст., коли процеси інкорпорації тільки набирали обертів, а патріотичні настрої українців і поляків були достатньо сильними.

Для придушення повстання у Царстві Польському терміново була створена армія у складі п'яти піхотних і двох кавалерійських корпусів загальною кількістю 183 тис вояків з 664 гарматами на чолі 3 генерал-фельдмаршалом графом І. Дібічем-Забалканским. Швидко збирали все, що було боєздатним у європейській частині імперії. До складу армії входили 1-й піхотний корпус генерала Палена 1-го; 2-й піхотний корпус Палена 2-го; 6-й піхотний корпус (колишній Литовський - А. С.) під командуванням генерала Розена, 3 ним гвардійський загін цесаревича; 3-й Поселений резервний кавалерійський корпус генерала Вітта, що дислокувався у Києво-Подільському поселенні; 5-й Поселений резервний кавалерійський корпус генерала Крейда 3 Херсонщини; Гренадерський корпус генерала Шаховського, Гвардійський корпус великого князя Михайла Павловича та 13 козацьких полків [16, с. 618]. Через великі втрати в турецькій кампанії 18281829 рр. та мізерну кількість солдатів у полках частини 3-го і 4-го піхотних корпусів безпосередньої участі в бойових діях 3 придушення повстання у Польщі не брали [24, с. 54].

Є підстави вважати, що на момент початку бойових дій у Правобережній Україні ситуативна стратегічна ініціатива була на боці повстанців. По-перше, у регіоні був відсутній фактор 
великої кількості російських регулярних військ: частина залишалися у Волощині після війни 3 Туреччиною, інші зосереджувалися для походу у Польщу; по-друге - місцева шляхта знала, що відбувається у Королівстві і готувалася до повстання; по-третє, холера, занесена військами, частково паралізувала можливості влади і поліції, вони утримували тільки губернські й повітові центри, більшість маєтків, сіл, селищ i містечок контролювали повстанці, маючи широкі можливості для маневру. Росіянам залишалося розраховувати на підкріплення 3 внутрішніх губерній, військових поселень і на підтримку проросійських мешканців губернських міст.

Київщина, як важлива і стратегічна частка України, ще з часів наполеонівських війн вважалася „південними воротами до великоросійських губерній”. Після закінчення війни з Туреччиною сюди почали повертатися війська, на які чекали нові розписи дислокації та розташування у складі 1-ї Армії [28, л. 1-4]. Рештки 2-го піхотного корпусу розташувалися на сході Волині та у північних повітах Київської губернії, на Наддніпрянщину прибули залишки 3-го піхотного корпусу (залишки 3-ї гусарської дивізії, 9-ї, 10-ї, 11-ї і 12-ї піхотних дивізій, 3-ї артилерійської дивізії та 3-го піонерного батальйону) [22, с. 667]. Ці маленьки частини отаборилися в районі Умані та частині південних повітів губернії, неабияк здивувавши місцеве населення своєю малою кількістю. 3 початком Листопадового повстання через свою низьку ефективність такі підрозділи використовувалися в пошуках зброї та амуніції, „на огляд лісів біля населених пунктів відправлялися військові команди та рекрути” [42, арк. 1-2; 4-19]. 3 метою відновлення боєздатності у квітні 1831 р. була створена Резервна армія, до складу якої увійшли усі резервні частини. Зокрема, в Києві та околицях тимчасово перебували резервні батальйони Литовського, Віленського, Брестського і Білостоцького полків 24-ї піхотної дивізії та Люблінського, Празького, Модлінського і Замостського 26-ї піхотної дивізії [40, арк. 1-2].

Вочевидь, російське командування не виключало можливості не тільки заворушень серед польського населення у Києві, а й вірогідність захоплення міста повстанцями [12, арк. 3]. Такі прецеденти існували. У Литві повстання набуло такого розмаху, що російським загонам ледь вдалося відбити поляків, які 
намагалися заволодіти містом Ковно, а частини Гвардійського корпусу готувалися захищати від них Брест-Литовський [31, с. 52]. 3 початком повстання, за наказом київського військового губернатора Б. Княжніна, мешканцями міста був відновлений озброєний Міщанський корпус. Реміснича управа виставила 1000 ремісників 316 цехів [13, арк. 3-3 зв.; 7-8]. За звітними документами, поданими Магістратом до губернатора, корпус на початку 1831 р. нараховував 500 вершників і більш ніж 2000 міщан ,,[...] з вогнепальною зброєю, міськими гарматами та власною музикою" [37, арк. 74-75].

Тим більше що саме в цей час 3 повітів до губернських центрів почали надходити тривожні рапорти чиновників міських $\mathrm{i}$ повітових поліцій. Так, київське губернське правління інформувало про ,[...] бродіння серед власників маєтків та дрібної шляхти у Таращанському, Липовецькому, Махнівському та Уманському повітах", яка планує захопити повітові міста [33, c. 214]. Військових просили бути готовими до антидержавних виступів населення Київської губернії. Відчуваючи небезпеку, армія одразу ж взяла на себе домінуючу функцію у боротьбі 3 польським визвольним рухом. За відомостями поліції, майже у кожному з повітів сформувалися загони кількістю від 200 до 300 осіб. Втім, після перших сутичок з російськими солдатами вони були розсіяні, а невелика кількість приєдналася до повстанців на Поділлі. Ще одним важливим завданням командування на той момент була швидка передислокація 3-го і 5-го Поселених кавалерійських корпусів 3 їх постійних квартир до кордонів Царства Польського, а саме у Подільську і Волинську губернії. Місцеві війська отримали завдання охороняти кінноту від нападів поляків, взявши під контроль шляхи та населені пункти [8, с. 2].

Після поразки поляків під Дашовим росіянам вдалося локалізувати й витіснити повстанські загони з території Київської губернії та в короткий термін узяти під контроль основні повітові центри. У м. Сквирі базувався Ніжинський полк і кінно-артилерійська № 26 рота з 1-ї кінно-єгерської дивізії; у Звенигородці резервний батальйон Охотського піхотного полку; в Умані - 35-й єгерський полк; Радомишлі - 47-й; Брусилові - 48-й єгерські полки. У Білій Церкві зі складу 25-ї піхотної дивізії резервні 
батальйони Подільського, Житомирського, 51-го і 52-го єгерських полків; у Махнівці - Ольвіопольський полк 4-ї Уланської дивізії та батальйони Волинського і Мінського полків; у Василькові резервні батальйони 49-го і 50-го єгерських полків [43, арк. 137138 3в].

Польське повстання 1830-1831 pр. на Поділлі спалахнуло переважно серед шляхти і стало реалізацією певних соціальних очікувань. Безумовно, головні події розгорталися в Царстві Польському, але існувала низка мілітарних чинників, які дозволили зібрати тисячні загони повстанців з артилерією, які до весни 1831 р. володіли певною військовою перевагою та ініціативою Відсутність армійських частин та їх нечисленність на місцях постійного перебування (про що йшлося вище. - А. С.), які не могли повністю й ефективно контролювати всю територію губернії; попри карантинні заходи на кордоні армія все ж таки занесла холеру, населення і війська були ізольовані медиками в гарнізонах; слабкість та інертність поліції та місцевих військ, тобто повітових інвалідних команд та губернського внутрішнього батальйону, які не впоралися з головним завданням недопущення поширення повстання і захоплення повітових міст і містечок.

Відомо, що прапор повстання підняли поміщики Ольгопільського повіту брати Собанські, а наприкінці квітня 1831 р. їх загін на Поділлі нараховував близько 6 тисяч осіб під командою відставного, але досвідченого генерала Б. Колишка, обраного головнокомандувачем усіма силами на півдні [38, арк. 48; 127-136]. Старий генерал одразу ж почав припускатися стратегічних помилок. По-перше, попри гучну посаду, він не зміг об'єднати зусилля усіх загонів, скоординувати їх дії та налагодити зв'язок з повстанцями Київщини i Волині. По-друге, повстанці 3 західних повітів Поділля, довідавшись про його плани з'єднання 3 корпусом Ю. Дверницького та почувши про наближення військ, піддались паніці й відступили через кордон до Галичини, чим негайно скористалися росіяни, легко взявши під контроль ці території. Швидко зосередивши 2-гу бригаду 3-ї уланської дивізії, вони завдали поразки загону шляхтича Ушицького біля села Ушиця, а самого ватажка взяли у полон, таким чином придушивши останній спротив [11, с. 206]. 
Водночас 3 півдня форсованим маршем 3 Бессарабії до Кам'янця-Подільського прибув генерал Л. Рот з 1-ю бригадою 4-ї уланської дивізії, 35-м єгерським полком та артилерією, зі складу 5-го піхотного корпусу. Зі сходу насувався генерал-лейтенант $\mathrm{X}$. Рейтерн 3 Бузькою посиленою уланською дивізією. Таким чином, загони Б. Колишка опинилися у лещатах, втративши можливість для маневру. 2 травня 1831 р. в упертому бою біля містечка Дашова росіянам вдалося розбити великий повстанський загін із семитисячної кінноти і півтисячної піхоти з гарматами, що припинило хвилювання в краї і змусило „неспокійні елементи втікати за кордон” [39, арк. 1-4].

Зважаючи на небезпеку повторних виступів влітку на Поділля перебазували 18-ту і 19-ту піхотні дивізії 5-го піхотного корпусу, а до середини листопада майже всі його частини перебували на території південно-західних губерній [23, с. 378]. Прибулі частини разом з уланами істотно посилили гарнізони в повітових містах і містечках губернії. Головним завданням військових став контроль за ситуацією та недопущення повторних виступів шляхти. Кам'янецький протоієрей Юліан Лотоцький писав: „,[...] коли поляки почали задумувати рухавку, з'явилися козаки для спостереження за ними [...] [35, с. 347]". Дійсно, незабаром на допомогу уланам прибули три козачих полки, сформованих за наказом царя в Малоросійській губернії, що дало можливість завдяки впровадженню регулярних роз'їдів (патрулів - А. С.) контролювати великі території повітів [26, с. 338].

3 початком польського Листопадового повстання Волинь опиняється в центрі уваги протиборчих сил як один із регіонів, де можливі загострення соціально-політичних протиріч. 3 обнародуванням маніфесту 25 січня 1831 р. про „Вступ Діючої армії до меж Царства Польського для угамування заколотників" розпочинаються активні бойові маневри [25, с. 295]. Раптом у Головному штабі з'ясувалося, що на важливих ділянках західного кордону імперії немає достатньої кількості військ, здатних його захистити. По-перше, штабісти не врахували потенційної небезпеки з цього напрямку; по-друге, старі плани дислокації військ стали неактуальними, а нових не було. Все, що мали росіяни на той момент у західних повітах Волинської губернії, це кадрована 11-та піхотна дивізія (близько 1000 солдатів), яка була неспроможна ефективно протидіяти корпусу польського генерала Ю. Дверницького. 
Тривалий час історія експедиції цього з'єднання є предметом наукових дискусій. Прославляння і героїзація генерала та його вояків з боку польських істориків зрозуміла. Росіянам довелося не тільки повоювати, а й добряче побігати за поляками, зрештою оточивши і відтіснивши їх до Галичини. Однак до кінця не з'ясовано та об'єктивно не проаналізовано низку моментів суто військового характеру.

Перший з них - кількість особового складу. У різних авторів вона коливається від 4 до 7 тисяч вояків, що перебували у складі 4 бригад 312 гарматами. Зрозуміло, що одні перебільшували іï, щоб показати свою звитягу, інші - применшували, щоб продемонструвати героїзм і самопожертву [18, с. 111-112; 30, с. 51-52]. Безперечно, в ході експедиції кількість вояків змінювалася. Однак ситуативні підкріплення, бойові втрати і дезертирство наводять до цифри не більшої ніж чотири тисячі.

По-друге, архівні джерела повідомляють, що на початку 1831 року у штабі 1-ї Армії стало відомо про наміри генерала. Шпигуни доповідали: до Любліна приїздила депутація від волинської шляхти із запевненням про те, що коли він з'явиться у краї, до нього приєднаються , [...] близько 8000 Козаків і Лісовиків, які повністю готові й озброєні піками та іншою зброєю, що зберігається в лісах під снігом [...]" [42, арк. 1-2]. Обіцянки магнатів Чапського і Стецького про формування двох полків на підсилення корпусу та розрахунок на допомогу вихованців Кременецького ліцею, які добре підготувалися і при нагоді мали приєднатися, вплинули на остаточне рішення Ю. Дверницького.

Похід поляків на Волинь був з самого початку приречений на поразку. Насамперед, виникає питання, як досвідчений командир довірився обіцянкам i не здійснив власних розвідувальних заходів, перетнувши кордон наосліп, не знаючи достеменно, що його насправді чекає. Тому він швидко втратив елемент несподіванки і тактичну ініціативу, внаслідок чого, не зумів з'єднатися 3 місцевими повстанськими загонами, не отримав обіцяного підкріплення i змушений був маневрувати на обмеженій території, що в поєднанні з енергійними діями росіян призвело до витіснення його за кордони імперії та згасання повстання. 
Розуміючи небезпеку об’єднання, росіяни одразу взялися шукати польські загони у районі Луцька i ВолодимираВолинського. В останньому 6 квітня 1831 р. граф Людвіг Стецький на чолі повстанців захопив владу i проголосив Тимчасове Правління під проводом графа Добржинського. У той самий день кавалерійський загін генерала Д. Давидова, який шукав корпус Дверницького, у складі Фінляндського драгунського полку i трьох козачих полків завдав поразки полякам i 3 боєм вибив їх загін із міста [10, с. 387-392]. Окремі загони діяли в Овруцькому повіті на чолі 3 предводителем дворянства Головинським, біля міста Чуднова Житомирського повіту - на чолі з поміщиком К. Рожицьким, у Ковельському, Луцькому та Рівненському повітах діяли К. Годебський, С. Ворцель та Н. Олізар, але згодом були розбиті російськими військами [21, с. 275].

3 Подільської губернії терміново на північ відправили 4-й резервний кавалерійський корпус генерала Ф. фон Редігера (1-ша драгунська і 1-ша кінно-єгерська дивізії). Перед ним стояло два завдання: перше - за будь-яку ціну не пустити Ю. Двірницького на територію губернії; друге - придушити місцевий партизанський рух.

Щоб остаточно закріпити досягнуті результати, Волинську губернію швидко наповнили військами, перекинутими 3 Київщини та Лівобережної України. Їх завдання полягало в недопущенні поширення повстання. У губернському Житомирі перебували війська: 3 3-го піхотного корпусу 8-ма піхотна дивізія; 3 4-го піхотного корпусу - 25-й і 26-й єгерські полки 13-ї піхотної дивізії, артилерія 10-ї і 13-ї бригад, 11-й Оренбурзький козачий полк, 1-ша бригада 4-ї уланської дивізії, 2-га бригада 1-ї кінноєгерської дивізії, квартермейстерська № 21 рота, Житомирський гарнізонний батальйон та житомирська жандармська команда (близько 10 тисяч вояків) [31, 215].

У повітових центрах стояли змішані гарнізони, підкріплені артилерією [44. арк. 1-10; 25; 39 ]. У Бердичеві - Вознесенський уланський полк і кінно-артилерійська рота № 22, 3 1-ї кінноєгерської дивізії - 2-га бригада і кінно-артилерійська рота № 26 та піший резерв 3-ї гусарської дивізії (всього 2 тисячі); в Старокостянтинові й Западинцях - дві бригади 9-ї піхотної дивізії (2 тисячі); в Острозі - 1-ша бригада 1-ї кінно-єгерської дивізії і рота артилерійської батареї № 25 (700 солдатів); в Заславлі - 3-тя бригада 9-ї піхотної дивізії, легка артилерійська рота № 3, кінноартилерійська № 24 рота 2-ї артилерійської бригади (1500 вояків); 
в Кремінці - Охтирський гусарський полк, 52-й єгерський полк 26-ї піхотної дивізії (1 тис.); в Радзівілові - Єлецький полк 11-ї піхотної диві; в Дубно - штаб 3-го піхотного корпусу і штаб 11-ї піхотної дивізії, по околицях - бригади цієї дивізії (2 тисячі); в Луцьку - штаб 3-ї гусарської дивізії і три драгунських полки (2 тисячі) [43, арк. 22; 34; 98; 1014 134-138; 150-151]. Отже, за архівними джерелами, для придушення повстання та контролю на Волині росіяни використовували 20-тисячне угруповання, яке входило до складу трьох армій: Діючої (на території Царства Польського), 1-ї Армії (західні губернії) та Резервної (Правобережна Україна, частково Новоросія з Кримом) [31, с. 216]. Поразка генерала Колишка на Поділлі та прибуття на Волинь дев'яти козацьких полків, які розташувалися в повітових центрах та почали патрулювання ,,[...] для охорони внутрішнього порядку, державних установ, пошт, магазинів і складів”, призвело до згасання виступів [36, с. 105].

Висновки. Отже, повстанські загони С.- Г. Ворцеля на Волині, К. Ружицького на Житомирщині, Б. Колишка на Поділлі й Київщині у квітні-травні 1831 року зазнали поразки в боях із царською армією, не досягнувши стратегічної мети - відновлення Речі Посполитої. Її причини криються, по-перше, у відсутності плану дій та єдиного керівництва, часто ватажки загонів діяли на власний розсуд; по-друге, наслідком децентралізації стала втрата тактичної ініціативи, чим і скористалися росіяни; по-третє, повстанці у Правобережній Україні були впевнені, що вторгнення корпусу Ю. Дверницького на Волинь і Поділля слугуватиме потужним імпульсом для його розвитку та встановлення централізованого командування, а генерал вбачав своїм головним завданням допомогти і підсилити місцевих повстанців. Невірні розрахунки і плани стали фатальним чинником, що й призвело до поразки поляків навесні 1831 року.

1. Gąsowski T. Konsekwencje powstań narodowych w XIX wieku dla polskiej tożsamości narodowej // SCIAGA.pl. електрон. наук. вид. URL: http://sciaga.pl/tekst/58014-59sens_powstan_narodowych_w_xix_wieku (дата звернення: 12.05.2016).

2. Kieniewicz S., Zahorski A., Zajewski W. Trzy powstania narodowe: kościuszkowskie, listopadowe, styczniowe. Pod redakcją Władysława Zajewskiego. Warszawa: PWN, 1992. $671 \mathrm{~s}$.

3. Kozlowski E. Golynski A. Pamitnik Podolskiego powstania 1830-1831 roku. Warszawa: Instytut wydawniczy Pax, 1979. $224 \mathrm{~s}$. 
4. Lelewel J. Porównanie dwu powstańnarodu polskiego 1794 i 1830-1831. Prawnośći korona; oraz przypiski do dziejów polskich potocznie opowiadanych. Paryz: W ksiegarni J. Marylskiego I Spolski. 1840. 158 s.

5. Mochnacki M. Powstanie narodu polskiego w roku 1830 i 1831. T. 2. Warszawa, 1984. 257 s.

6. Powstanie Listopadowe 1830-1831. Dzieje wewnętrzne. Militaria. Europa wobec powstania. / pod redakcją W. Zajewskiego. Warszawa: 1990. 377 s.

7. Wrotnowski F. Powstanie na Wołyniu, Podolu I Ukrainie w roku 1831. Podlug podańdowódzców i współuczęstników tegożpowstania. Paryż: W księgarni I drukarni polskiej, 1837. Tom perchi. 350 s.; Wrotnowskiy F. Powstania na Wolyniu, Podolu i Ukrainii w roky 1831. Paryz: W ksiegarni i drucarni polskiej. 1838. Tom drugi. $401 \mathrm{~s}$.

8. Внугренние известия // Русский инвалид. 25 октября 1830 г. № 272. С. 2.

9. Геллер М. Я. История Российской империи. В двух томах. Том 2. Москва: МИК, 2001. - С. 332.

10. Генерал-лейтенант Денис Васильевич Давыдов / Жизнеописания русских военных деятелей / под ред. В. Мамышева. Том 1. Вып. первый. Санкт-Петербург: изд. В. Березовский, 1885. - С. 387-392.

11. Годунов B. История 3-го Уланского Смоленского Императора Александра III полка. 1708-1908. Либава: Типо-литография Либавский вестник, 1908. - С. 206.

12. Державний архів міста Києва, Ф. 1, Оп. 2, Спр. 1626 , арк 3.

13. Там само, Спр. 1627, Арк 3-3зв; 7-8.

14. Западные окраины Росссийской империи / научн. ред. М. Долбилов, А. Миллер. Москва: Новое литературное обозрение, 2006. - С. 71.

15. Из записок современника. О Пинской бригаде польских войск. Частичка из действий О. Суворова-Рымникского в 1794 году // Московитянин. 1842. № 2. С. 61.

16. История русской армии и флота / ред. А. С. Гришинский, В. П. Никольский, Н. Л. Кладо. В. 15 томах. Т. І. Москва: изд. Образование, 1911. - С. 618.

17. Каспарек Н. Події польського повстання 1830-1831 pp. на Правобережній Україні // Польське національне повстання 1830-1831 pр. на Правобережній Україні: від міфів до фактів : кол. монографія / за ред. І. Кривошеї, Н. Моравця. - Київ: КНТ, 2017. - С. 109-133.

18. Каспарек Н. Шлях польських загонів із Поділля й Волині на Галичину в 1831 році. // Польське національне повстання 1830-1831 pр. на Правобережній Україні: від міфів до фактів : кол. монографія / за ред. І. Кривошеї, Н. Моравця. Київ: КНТ, 2017. С. 111-112. 
19. Кривошея I. I. Шляхта Уманщини в імперську добу (кінець XVIII - перша половина XIX ст.). - Умань: ВПЦ «Візаві». 2014.- 254 с.

20. Опытов М. Волынская революция первой четверти XIX столетия (Письма надворного советника Опытова к графине Старожиловой) // Киевская старина. Год второй. T. V.- Киев: Тип. Г. Т. Корчак-Новицкого, 1882. - С. 136; 138.

21. Петров Н. И. Волынь. Исторические судьбы ЮгоЗападного края. - Санкт-Петербург: 1888. - С. 275.

22. Полный свод законов Российской империи (ПСЗРИ)-II. Т. IV. № 3178; Т. V. Отд. 2. № 4100.

23. ПСЗРИ-ІІ. Т. VІ. Отд. 1. № 4285.

24. ПСЗРИ-II. Т. VI. Отд. 1. № 4490.

25. ПСЗРИ-II. Т. VІ. Отд. 1. № 4536.

26. Российский государственный военно-исторический архив, Ф. 103. Оп. 2г. Д. 3. л. 11.

27. Российский государственный архив древних актов, Ф. 1261, Оп. 1, Д. 2200, л. 1-4.

28. Романюк I. Польське населення східного Поділля в листопадовому повстанні // Польське національне повстання 1830-1831 рр. на Правобережній Україні: від міфів до фактів : кол. монографія / за ред. І. Кривошеї, Н. Моравця. Київ: КНТ, 2017. С. 184-191.

29. Русская военная сила. Очерк выдающихся военных событий от начала Руси до наших дней. изд. И. Н. Кушнерева Вып. IX. - Москва: 1889. - С. 31-32.

30. Русская военная сила. Очерк развития выдающихся военных событий от начала Руси до наших дней. изд. И. Н. Кушнерева. Вып. Х. - Москва, 1889. - С. 52.

31. Скрипник A. Ю. Російський військовий чинник у суспільно-політичному та економічному розвитку Правобережної України (1792-1865 рр.): монографія / Кам'янецьПодільський: - Вид. ФОП Зволейко Д. Г., 2016. - С. 216.

32. Скрипник $A$. Ю. Київська губернія як стратегічний район перебування російської армії наприкінці XVIII першій половині XIX ст. // Проблеми історії України XIX - початку XX ст: зб. Київ, Інститут історії України НАН України. 2013. Вип. ХХІІ. С. 203-216.

33. Тромбський М. Від Житомира до Замостя: партизанський рейд загону Кароля Ружицького під час Листопадового повстання // Польське національне повстання 1830-1831 pp. на Правобережній Україні: від міфів до фактів : кол. монографія / за ред. І. Кривошеї, Н. Моравця. - Київ: КНТ, 2017. - С. 134-146.

34. Труды Подольского Церковного историкоархеологического обществаю Вып. одиннадцатый / под ред. Е. Сецинского и Н. Яворского. - Каменец.Подольский: 1911. - С. 347. 
35. Там само. С. 105.

36. Центральний державний історичний архів України м. Києві (ЦДІАК України), Ф. 442, Оп. 1, Спр. 474, Арк. 74-75.

37. Там само, Оп. 782, Спр. 155, Ч. I, Арк. 48; 127-136.

38. Там само, Оп. 783, Спр. 30, Арк. 1-4.

39. ЦДІАК України, Ф. 533, Оп. 3, Спр. 519, Арк. 1-2.

40. Там само, Оп. 4, Спр. 123, Арк. 1-2.

41. Там само, Спр. 125, Арк. 1-2; 4-19.

42. Там само, Оп. 5, Спр. 590, Арк. 137-138зв.

43. Там само, Спр. 591, Арк. 1-10: 25: 39.

44. Чичерин Б. Воспоминания. В 2-х т. Т. 1. Москва сороковых годов. Путешествие за границу. - Москва: 2010. - С. $92 . \quad$ Режим доступу: http://www.biblioclub.ru/index.php? page=book\&id= 226585 .

45. Ярмошик I. I. Військові події на Волині в ході польського листопадового повстання 1830-1831 pp. у світлі польської історіографії. // Воєнна історія України. Волинь та Полісся. - Київ: Національний музей історії України, 2013. - С. 183-188.

Надійшла до редколегії 22.04.2018 p.

\section{Skrypnyk A. \\ MILITARY OPPOSITION IN NOVEMBER REVOLT 1830-1831 IN RIGHT-BANK UKRAINE}

The article is devoted to the analysis of the armed antagonism of parts of the Russian imperial army with detachments of Polish insurgents during the events of the November uprising in 1830-1831 in the Right-Bank Ukraine. The motivational factors of the opposing sides, the balance of forces, their location, armed clashes and maneuvers, tactical successes and miscalculations are considered and elucidated. The object of the study is the territory of the region considered as a theater of military actions in accordance with the existing administrative-territorial division of the time.

During four months in 1831, there was a persistent and dramatic fight covering almost all ethnic and social groups in each of the regions (territories around Kyiv, Podillia, Volyn) in the Right-Bank Ukraine. Beside the political issue directing the revival of sovereignty, the basic type of resistance was the armed one. Accordingly, the Russian autocracy relied on the powerful and radical solution of the problem. As a result, there are Polish military forces (in particular, General U. Dvernytskyi's corps and insurgent detachments of gentry) on one side and regular parts of the Russian Emperor's Army, irregular cossack regiments from Left-Bank Ukraine and auxiliary subdivisions of the Internal watch corps (province battalions and district squadrons) on the other. Thus the investigation of Polish-Russian military opposition is the purpose of this paper and dwells on the specifically military issue.

Keywords: Right-bank Ukraine, Russian army, Polish rebels, warfare, dislocation, hostility. 